\title{
Recent Advances in the Synthesis of Oxazole-Based Molecules via van Leusen Oxazole Synthesis
}

\author{
Xunan Zheng ${ }^{1,2}$, Wei Liu ${ }^{3, *}$ and Dawei Zhang ${ }^{1, *}$ (i) \\ 1 College of Chemistry, Jilin University, Changchun 130012, China; zhengxn8217@mails.jlu.edu.cn \\ 2 College of Plant Science, Jilin University, Changchun 130062, China \\ 3 Department of Pesticide Science, Plant Protection College, Shenyang Agricultural University, \\ Shenyang 110866, China \\ * Correspondence: liuwei871016@sina.com (W.L.); z_dw@jlu.edu.cn (D.Z.); \\ Tel.: +86-188-1775-2588 (W.L.); +86-431-8783-6471 (D.Z.)
}

Academic Editors: Anna Carbone and Fabio Bertozzi

Received: 2 March 2020; Accepted: 23 March 2020; Published: 31 March 2020

check for updates

\begin{abstract}
Oxazole compounds, including one nitrogen atom and one oxygen atom in a five-membered heterocyclic ring, are present in various biological activities. Due to binding with a widespread spectrum of receptors and enzymes easily in biological systems through various non-covalent interactions, oxazole-based molecules are becoming a kind of significant heterocyclic nucleus, which have received attention from researchers globally, leading them to synthesize diverse oxazole derivatives. The van Leusen reaction, based on tosylmethylisocyanides (TosMICs), is one of the most appropriate strategies to prepare oxazole-based medicinal compounds. In this review, we summarize the recent advances of the synthesis of oxazole-containing molecules utilizing the van Leusen oxazole synthesis from 1972, aiming to look for potential oxazole-based medicinal compounds, which are valuable information for drug discovery and synthesis.
\end{abstract}

Keywords: van Leusen; TosMICs; oxazole; synthesis

\section{Introduction}

The oxazole ring, with one nitrogen atom and one oxygen atom, which are widely displayed in natural products and synthetic molecules, is known as a prime skeleton for drug discovery. On the account of structural and chemical diversity, oxazole-based molecules, as a central scaffold, not only enable different types of interactions with various receptors and enzymes, showing broad biological activities, but also occupy a core position in medicinal chemistry, showing their enormous development value and they favored the discovery of newer potential therapeutic agents [1-5]. Consequently, a wide variety of oxazole-containing compounds, as clinical drugs or candidates, have been frequently employed, which play a vital role in the treatment of diverse types of diseases like antibacterial [6-8], antifungal [9-11], anti-inflammatory [12-14], antiviral [15-17], anti-tubercular [18-20], anticancer [21-23], anti-parasitic [24-26], antidiabetic [27-29], and so on. The marketed drugs containing the oxazole ring system with medicinal value are being actively exploited worldwide. Various pharmacological activities and chemical structures of oxazole-based molecules are enumerated in the following Table 1. 
Table 1. The pharmacological activities and chemical structures of typical oxazole-based molecules.

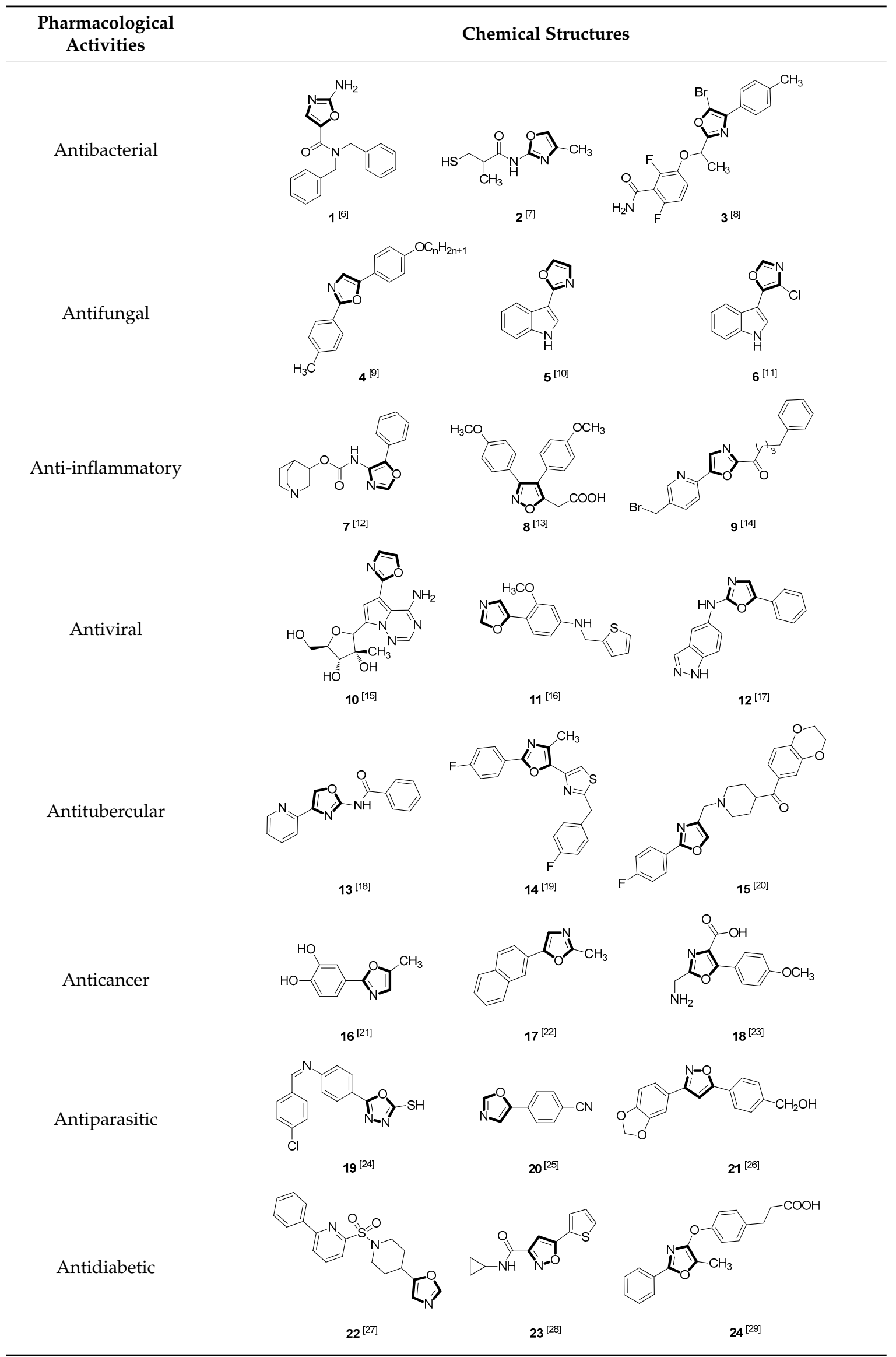


Due to the diversity of therapeutic response profiles, the chemical synthesis of oxazole and its derivatives has become a key objective and has drawn much attention of current pharmacologists and chemists around the globe to be explored exhaustively for the benefit of mankind. Until now, many ingenious oxazole synthesis methodologies have been developed, including the van Leusen reaction [30], Cornforth reaction [31], Fisher reaction [32], Doyle reaction [33], Dakin-West reaction [34], as well as Robinson-Gabriel reaction [35], etc.. Among these synthetic strategies, it is well-known that the van Leusen oxazole synthesis, based on tosylmethylisocyanides (TosMICs), is one of the most convenient and attractive protocols for the preparation of oxazole-based molecules, owing to its excellent virtues like simple operation, easily obtained raw materials, and a broad substrate scope, and it has been developed rapidly in the past decades. It is worth mentioning that the pharmacological activity oxazole-based compounds 11, 16 and 25 in Table 1 can be obtained by van Leusen reaction as a key step.

TosMIC, a kind of the most significant reactants, has many good features at room temperature including stable solid, odorless, and colorless. Since it was introduced and applied in organic synthesis by the Dutch professor van Leusen in 1972, this reagent is also known as van Leusen's reagent. Today, TosMIC and its derivatives have been recognized as one of the most significant building blocks in organic synthesis and a great deal of reaction scenarios, which have been fruitfully employed in the preparation of pyrrole-, imidazole-, and oxazole-based five-membered heterocyclic molecules [36-40]. General van Leusen synthesis base on TosMICs is summarized in Scheme 1.

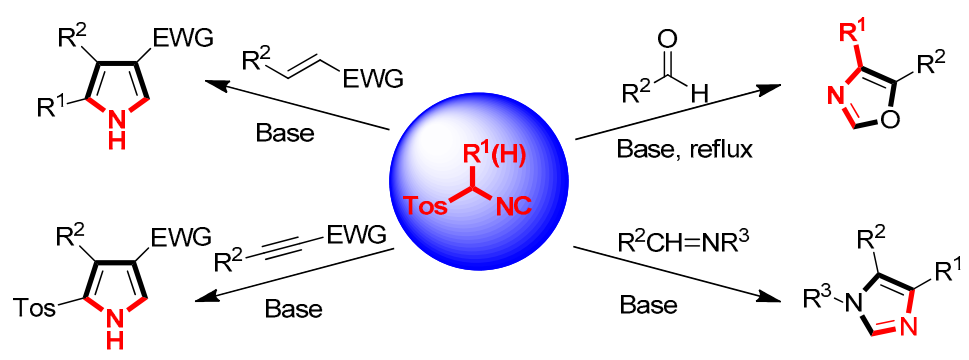

Scheme 1. General van Leusen synthesis base on tosylmethylisocyanides (TosMICs).

Based on our previous research, we have published two reviews about the van Leusen reaction for the preparation of pyrrole- and imidazole-based molecules [41,42]. Therefore, this review, which covers the literature from 1972, will summarize the recent advances of the synthesis of oxazole-based molecules utilizing the van Leusen oxazole synthesis as an important part of van Leusen reaction, which is the [3+2] cycloaddition reaction based on TosMICs. Meanwhile, it is expected that this review article will be beneficial for fresh opportunities to search for a reasonable design for oxazole-containing drugs.

\section{General van Leusen Oxazole Synthesis}

In 1972, van Leusen et al. first discovered a novel chemical strategy for the formation of oxazole-based heterocyclic ring systems. In this study, 5-substituted oxazoles 29 were obtained from aldehydes $\mathbf{2 8}$ and TosMIC $\mathbf{2 5}$ as a precursor in a one-pot reaction under mild condition, which is widely known as the van Leusen oxazole synthesis (Scheme 2) [30].

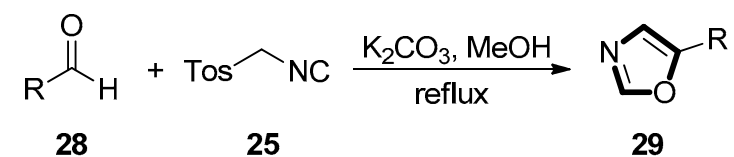

Scheme 2. The first example of van Leusen oxazole synthesis.

As shown in Scheme 3, the van Leusen oxazole synthesis allows the preparation of 5- substituted oxazole through a two-step [3+2] cycloaddition reaction from aldehydes with TosMICs under a base 
condition. In this process, the TosMIC contains reactive isocyanide carbons, active methylene, and leaving groups as C2N1 "3-atom synthon". After adding the deprotonated TosMIC to the aldehyde and bond formation between the resulting hydroxy group and the isocyano group, an oxazoline results as an intermediate. Then, with concomitant elimination of -TosH, the intermediates are given to the obtained 5-substituted oxazoles.

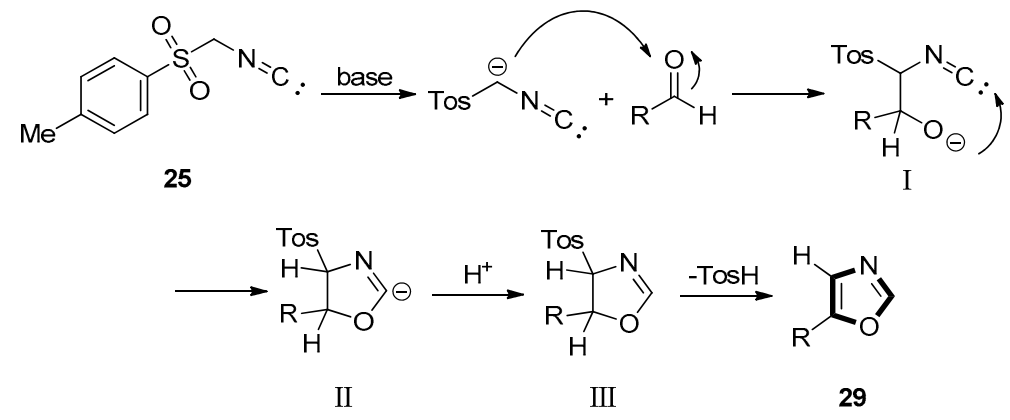

Scheme 3. Mechanism of van Leusen oxazole synthesis.

\section{Developments of the van Leusen Oxazole Synthesis}

In 1999, the Ganesan group developed a synthetic route of the 5-aryloxazoles 31. They utilized a new polystyrene- $\mathrm{SO}_{2}-\mathrm{CH}_{2}-\mathrm{NC}$ with polystyrene-SH resin as starting material in three steps for the preparation of an immobilized sulfonylmethyl isocyanide $\mathbf{2 5}^{\prime}$, in order to illustrate the isocyanide resin's potential. This protocol was similar to the solution-phase preparation of TosMIC or related analogues. Then, they used a quaternary ammonium hydroxide ion exchange resin to catalyze the reaction of TosMIC 25 with aromatic aldehydes 30 to generate the 5-aryloxazoles 31 . By analysis, they anticipated that polymer-supported-TosMIC (PS-TosMIC) and tetrabutylammonium hydroxide would be a realistic solid-phase replacement for other applications of TosMIC (Scheme 4) [43,44].

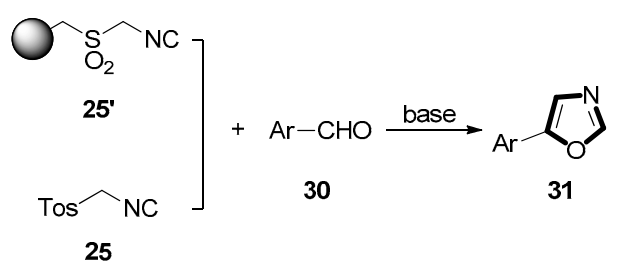

Scheme 4. Synthesis of 5-aryloxazoles 31.

In 2000, Sisko's group found that van Leusen reaction of aryl-substituted TosMIC reagents with aldehydes had not been relatively explored. Hence, they surmised these reactions should be particularly concise, require mild reaction condition, and be tolerant of a vast range of functional groups. Then, they proved through the experiment that similar cycloaddition reactions with available and multifunctional aldehydes proceed smoothly to generate a wide variety of interesting oxazole compounds with high yield. For example, methylketone 33 could be obtained in a good yield from pyruvaldehyde 32 and aryl-substituted TosMIC reagent 25 (Scheme 5) [45].

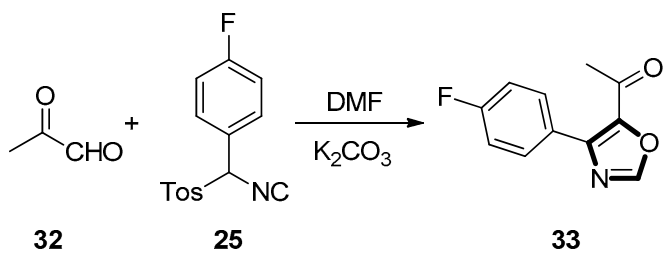

Scheme 5. Synthesis of methylketone 33 via aryl-substituted TosMIC reagent. 
In 2005, Chakrabarty et al. described a van Leusen route of 3/2-formylindoles with TosMIC to prepare corresponding indolyloxazoles and stable indolyl primary enamines. This reaction was provided in refluxing methanol and could complete quickly in 3-6 h. Besides the expected 5-(3-indolyl)oxazoles products, the novel rearranged indolyl primary enamines might be also formed. As shown in Scheme 6, two different results were obtained from substituted indole derivatives 34a on one hand and from $\mathbf{3 4 b}$ on the other hand. Specifically, each of 34a furnished two products, viz. 35 and 36, respectively. On the contrary, each of $34 \mathrm{~b}$ furnished only one type of products 36 . Likewise, as shown in Scheme 7, each of 37a generated two products 38 and 39, each of $\mathbf{3 7 b}$ furnished only one product 38. However, by testing 37c, the result was that the final product was only 39 [46].

As to the mechanism of the formation of compound 36, the intermediate products in the process of carboxylic acids through nitriles form aldehydes and ketones with TosMIC 25. Then, the lone pair of electrons on the indolic nitrogen triggers the protonation (from methanol) of the enamidic double bond, resulting in the indoleninium species. Subsequently, a 1,2-shift of the tosyl group with simultaneous neutralization of the indoleninium cation, followed by the loss of a proton, gives rise to the intermediate. A nucleophilic attack by methanol, followed by the loss of a molecule of methyl formate and subsequent protonation, gives rise to the enamines 36 .
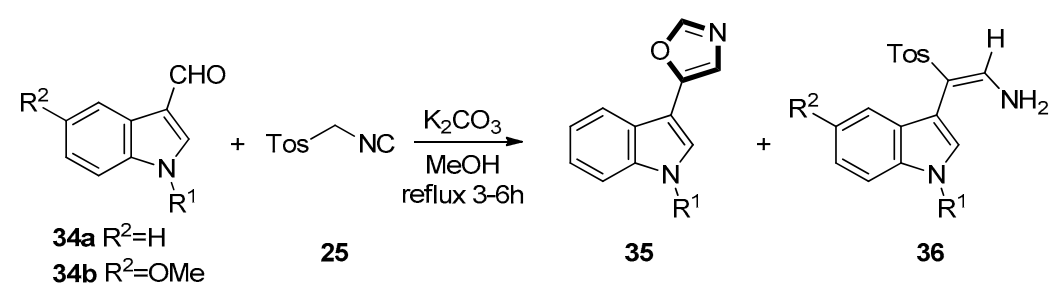

Scheme 6. The reaction of 3/2-formylindoles with TosMIC and 34.

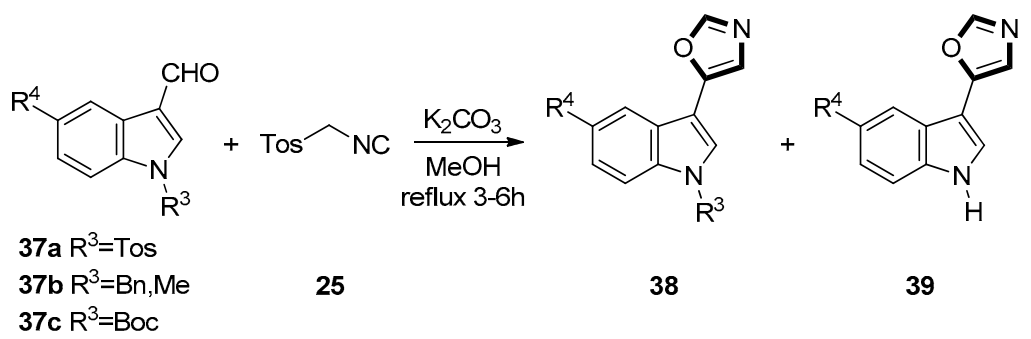

Scheme 7. The reaction of 3/2-formylindoles with TosMIC and 37.

In 2007, Kotha and co-workers reported that both $C_{2}$-symmetric and $C_{3}$-symmetric oxazole derivatives were synthesized through the stepwise Suzuki-Miyaura cross-coupling and the van Leusen synthesis. In this process, the raw materials of bis- and triscarboxaldehydes could be offered through a Suzuki-Miyaura cross-coupling reaction of corresponding arylboronic acid reagents. Then, the aldehydes were further treated with TosMIC 25 in the presence of $\mathrm{K}_{2} \mathrm{CO}_{3}$ in refluxing methanol to deliver the corresponding oxazole derivatives. The different products were generated surprisingly through changing the position and number of aldehyde groups. Specifically, when trialdehyde derivatives 40 were treated with TosMIC 25 in a typical reaction condition, the corresponding $C_{3}$-symmetric oxazole derivatives 41 were generated (Scheme 8, path A). After confirming 41, they also prepared other $C_{3^{-}}$ and $C_{2}$-symmetric oxazole derivatives 43 (Scheme 8 , path $B$ ) and 45 through changing the substrates 42 and 44, respectively (Scheme 8, path C) [47]. 


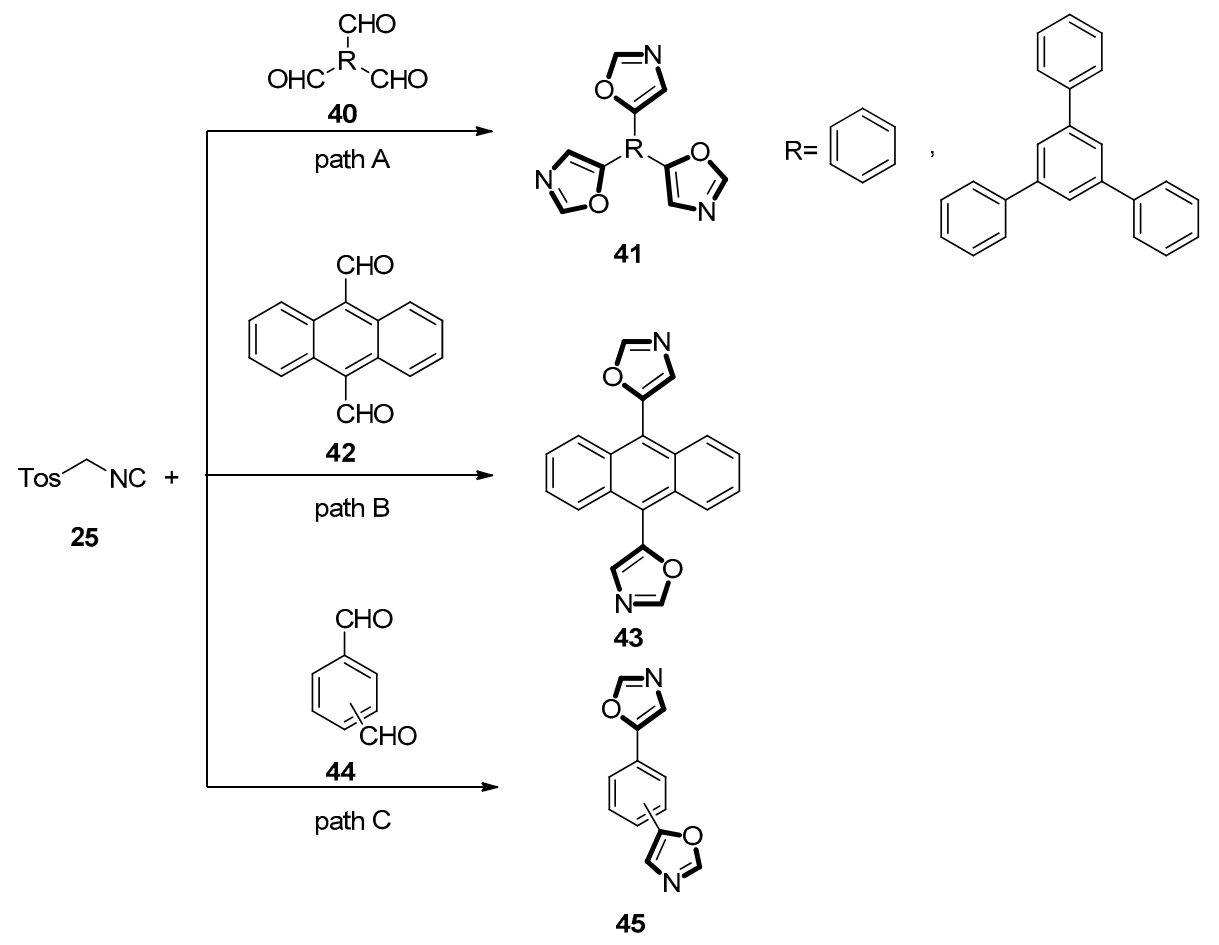

Scheme 8. Synthesis of $C_{2}$ - and $C_{3}$-symmetric oxazole derivatives 41,43 , and 45 .

In 2009, Yu and co-worker developed a van Leusen reaction to synthesize the 4,5-disubstituted oxazoles in a one-pot manner. The special characteristic of this reaction was the ionic liquid as solvent. The target oxazole products 48 were generated from TosMIC 25, various aldehydes 46 and aliphatic halides 47 . This reaction had a high yield and a broad substrate scope. Since the electron withdrawing group could facilitate the reaction, aromatic aldehydes substrates with electron withdrawing group exhibited higher reactivity. It is noteworthy that this reaction is eco-friendly and economical, since the ionic liquids can be recovered and reused as solvent for six runs without conspicuous loss of yield (Scheme 9) [48].

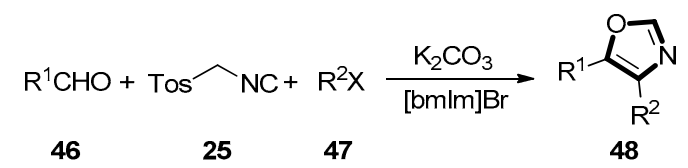

Scheme 9. A one-pot synthesis of 4,5-disubstituted oxazoles 48 in ionic liquid.

From 2011 to 2018, the Šindler-Kulyk group reported a series of reactions to synthesize the 5-substituted oxazole compounds.

In 2011, they described a novel approach for the synthesis of naphthoxazole and fused heterobenzoxazole derivatives. In this report, the starting 5-(aryl/furyl/thienyl/pyridyl ethenyl) oxazoles 50 were obtained through a van Leusen process between the corresponding $\alpha, \beta$-unsaturated aldehydes 49 and TosMIC 25 in a good yield. Then, the intermediate oxazoles underwent UV irradiation in aerobic condition in the presence of iodine, transforming into the naphthoxazoles $\mathbf{5 1}$ and other fused heterobenzoxazoles (Scheme 10, method A) [49].

In 2014, they also synthesized the novel trans-5-(2-vinylstyryl)oxazole 53 through the van Leusen reaction between trans-3-(2-vinylphenyl) acrylaldehyde 52 and TosMIC 25. The trans-3-(2-vinylphenyl) acrylaldehyde 52 was prepared through the Wittig reaction of ovinylbenzaldehyde and (formylmethylene) triphenylphosphorane. For the preparation of 5-(2-vinylstyryl) oxazole by this route, 3-(2-vinylphenyl) acrylaldehyde was needed. As the configuration of the starting aldehyde 52 
for the van Leusen reaction with TosMIC 25 was in trans configuration, the obtained corresponding product 5-(2-vinylstyryl)oxazole 53 retained the trans configuration (Scheme 10, method B) [50].

The same group synthesized the required $p$-and $o$-substituted 5 -arylethenyloxazoles 55 from the corresponding $\alpha, \beta$-unsaturated aldehydes 54 and the TosMIC 25 through the van Leusen reaction under a typical reaction condition in 2018. To further broaden the substrate scope of naphtho [1- $d$ ] oxazoles, other 5-(arylethenyl)oxazoles 55 were prepared from the corresponding aryl-substituted $\alpha$-unsaturated aldehydes $\mathbf{5 4}$ and TosMIC 25. This process took place as depicted above, treating with TosMIC in one-step synthesis through the van Leusen reaction (Scheme 10, method C) [51].

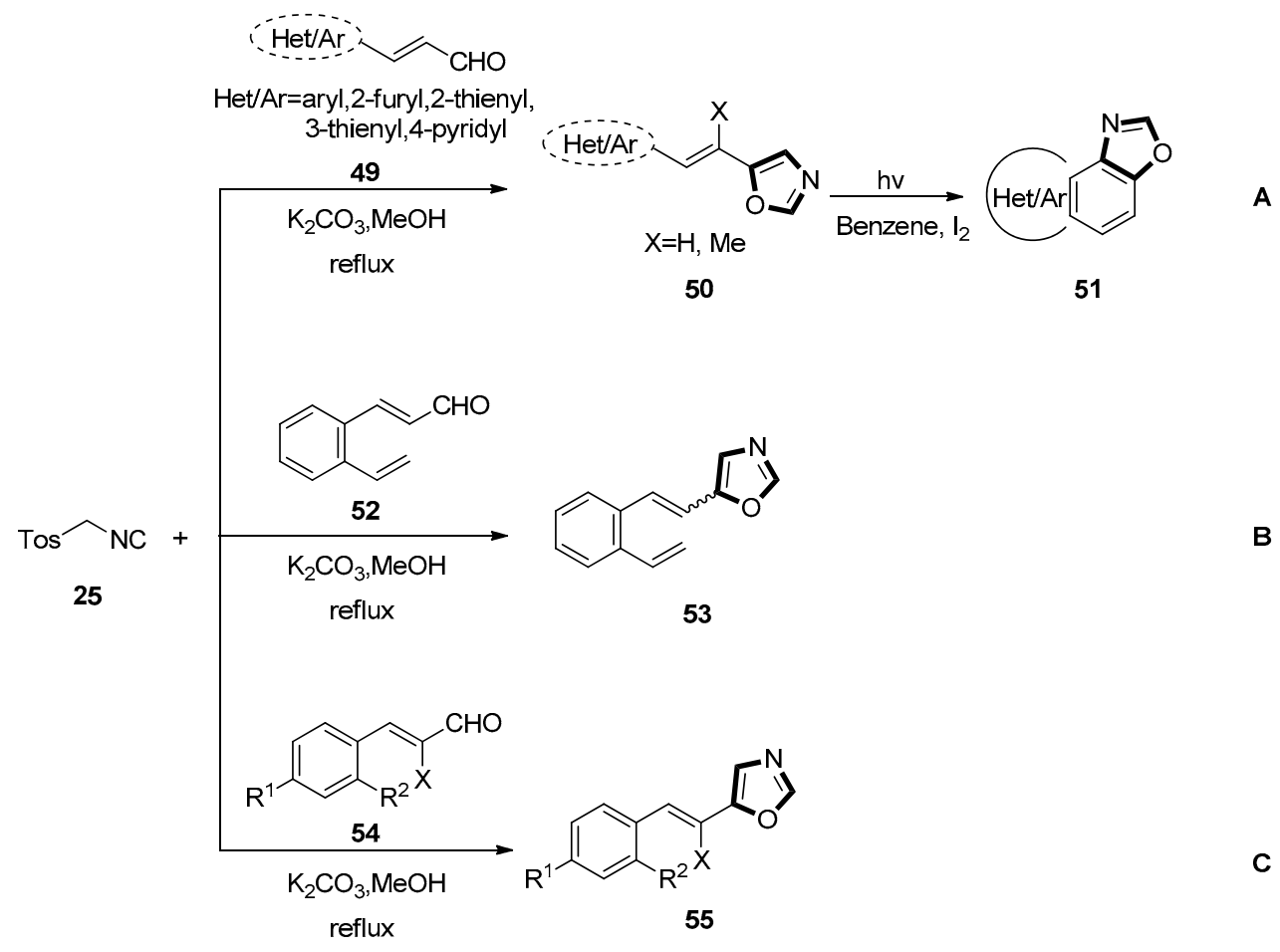

Scheme 10. Synthesis of naphthoxazoles and fused heterobenzoxazoles 51, trans-5-(2vinylstyryl)oxazole 53, and 5-(arylethenyl)oxazoles 55.

In 2011, Hamon and co-workers adopted a convergent process based on the cross-coupling of 2,6-bis(oxazol-5-yl) pyridine 57 and 2-bromopyridine 58 derivatives through the double C-H activation of the oxazole rings, to perform the synthesis of oligo-heteroaryles. As shown in Scheme 11, precursor 57 was obtained under the van Leusen oxazole synthesis condition with TosMIC 25 and pyridine-2,6-dicarbaldehyde $\mathbf{5 6}$ as starting material which was afforded through the oxidation of 2,6-lutidine. The Pd catalyzed coupling of 57 and 2-bromopyridine 58 under known condition to form the pentaheteroaryle BOxaPy 59 in a $45 \%$ yield. To generate TOxaPy $\mathbf{6 1}$ unambiguously, another novel process was devised in which terminal oxazole moieties were synthesized from the corresponding pentacyclic bisformyl intermediate $\mathbf{6 0}$ (Scheme 12). The key step for the synthesis of TOxaPy $\mathbf{6 1}$ was the classic van Leusen oxazole synthesis between aldehyde 60 and TosMIC 25, giving the target ligand TOxaPy 61 in a 50\% yield. In this process, it is worth mentioning that the ligand TOxaPy 61 has an unprecedented binding behavior with quadruplexes, which shows a good potential for further application in the anticancer drug discovery [52]. 

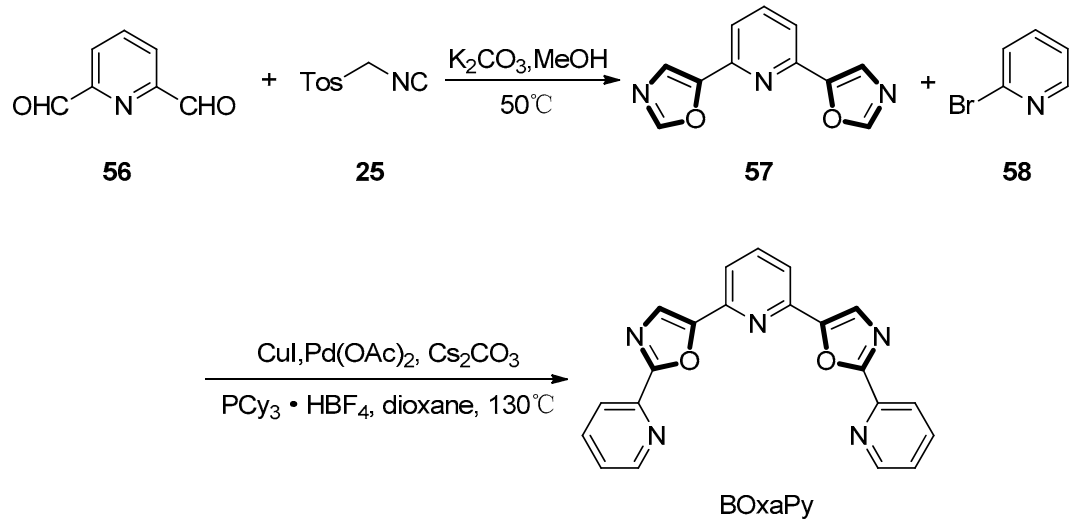

59

Scheme 11. Synthesis of BOxaPy 59.<smiles>O=Cc1cccc(-c2ncc(-c3cccc(-c4cnc(-c5cccc(C=O)n5)o4)n3)o2)n1</smiles>

60

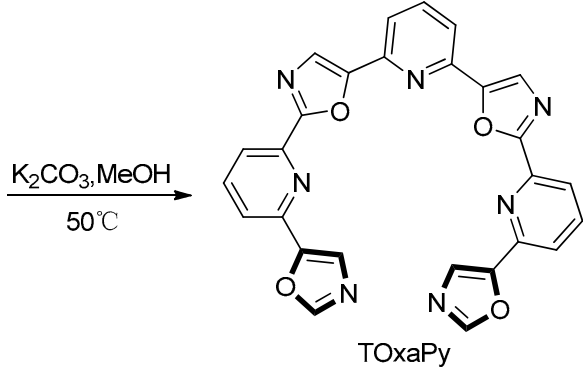

61

Scheme 12. Synthesis of potential anticancer drug TOxaPy 61.

In 2012, Zhang et al. developed a straightforward and efficient synthetic method to form 5-(3-indolyl)-oxazoles 64, further used to synthesize a class of products which were similar to the natural product pimprinine. The reaction, which was in a mixture of DME and methanol as solvent with TosMIC 25 from compound 62, afforded 5-(1H-indol-3-yl)oxazole 63 in a $66 \%$ yield in the presence of the ion exchange resin of Ambersep ${ }^{\circledR} 900(\mathrm{OH})$. By this way, they synthesized a sequence of pimprinine analogues and then tested their anti-fungal activities. The biological testing showed that some of the products display a broad spectrum anti-fungicidal activity against plant pathogens growing. At last, they found that seven of the products showing stronger activity were affirmed as the most prospective candidates for further study. Further structural optimization of pimprinine analogues was being well at present, alongside more precise biological testing of compounds with a high biological activity, in order to define their classes of fungicidal activity better (Scheme 13) [53].

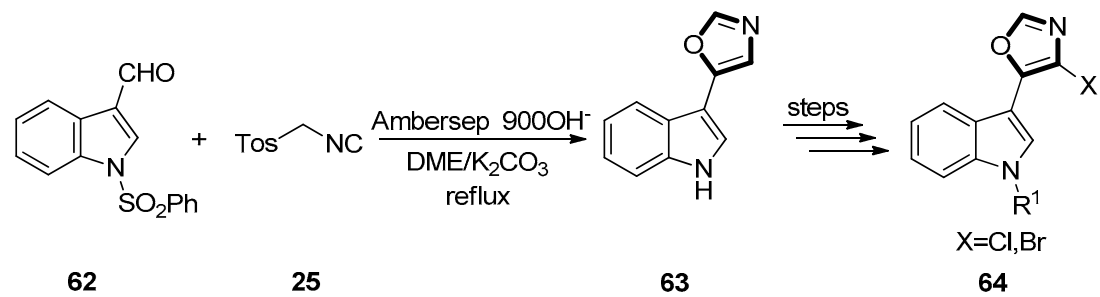

Scheme 13. Synthesis of potential artificial compound 64.

In 2013, Lee et al. published a protocol for the marine natural product streptochlorin. N-Boc protected aldehydes 65 were reacted with TosMIC 25 through a van Leusen reaction in the presence of $\mathrm{K}_{2} \mathrm{CO}_{3}$ as base in methanol, providing the desired oxazole compound 66. It was interesting that the Boc protection group got lost during this transformation. To compensate for the undesired deprotection of 
the Boc protective group, it was reprotected at the $N-1$ position to give compound 66. Then, further study was continued on this basis. In order to construct a series of streptochlorin-based, focused analog library, as well as the screening of additional bioactivities, researchers are now focusing on the further extension of the functional group tolerance and substrate scope of the above described synthetic sequences and the evaluation for additional bioactivities (Scheme 14) [54].

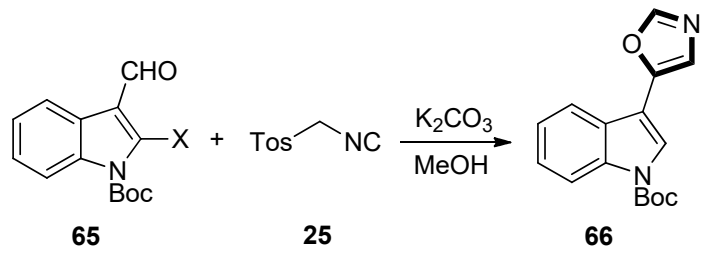

Scheme 14. The marine natural product streptochlorin analogue 66.

In 2015, the Georgiades group reported a new synthetic route, which contained only seven steps, to synthesize the unusual 'propeller-like' pyridyl-oxazole architecture with alternating pyridines and oxazole rings. This method utilized the van Leusen reaction for the construction of oxazole moieties with aldehydes as starting materials, two $\mathrm{Pd}(\mathrm{II}) / \mathrm{Cu}(\mathrm{I})$-mediated cross-coupling reactions including $\mathrm{C}-\mathrm{H}$ activation of oxazoles for the construction of $\mathrm{C}-\mathrm{C}$ bonds between bromopyridine intermediates and oxazole derivatives. As shown in Scheme 15,1,3-dipolar cycloaddition progress was carried out on two ketone moieties of 67 with the reagent TosMIC 25, under the condition of $\mathrm{K}_{2} \mathrm{CO}_{3}$ as base in refluxing methanol, making an efficient transformation of 67 into the target tris-oxazole compound 68 [55].

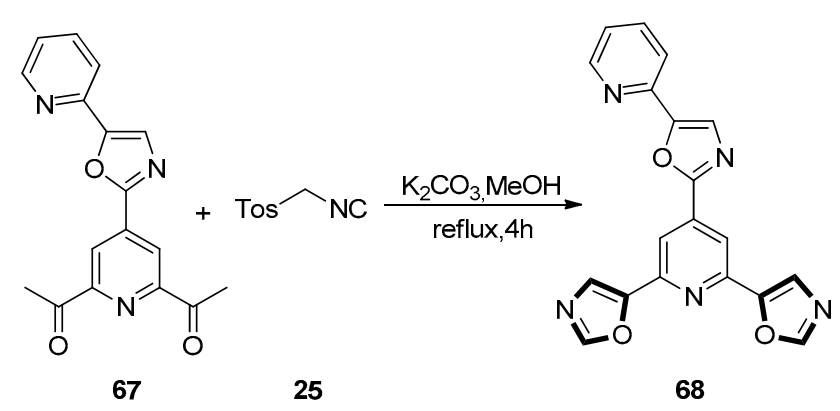

Scheme 15. Synthesis of 'propeller-like' anticancer biomolecular target 68.

In 2016, Shah et al. invented a preparation method of flexible tripodal 1,3-oxazoles through utilizing 1,3,5-trimethyl-benzene as a substrate for transformation into the $C_{3}$-sym-metric scaffolds. The tris-aldehyde substrates were synthesized from 1,3,5-tris(bromomethyl)-2,4,6-trimethylbenzene through coupling with different phenolic aldehydes under a basic condition in a high yield. Then, the van Leusen reaction was used to construct the oxazole rings between tris-aldehyde substrates 69 and TosMIC 25 with $\mathrm{K}_{2} \mathrm{CO}_{3}$ in refluxing methanol, giving the desired 5-substituted tris-oxazoles 70 in a good yield (Scheme 16) [56]. 


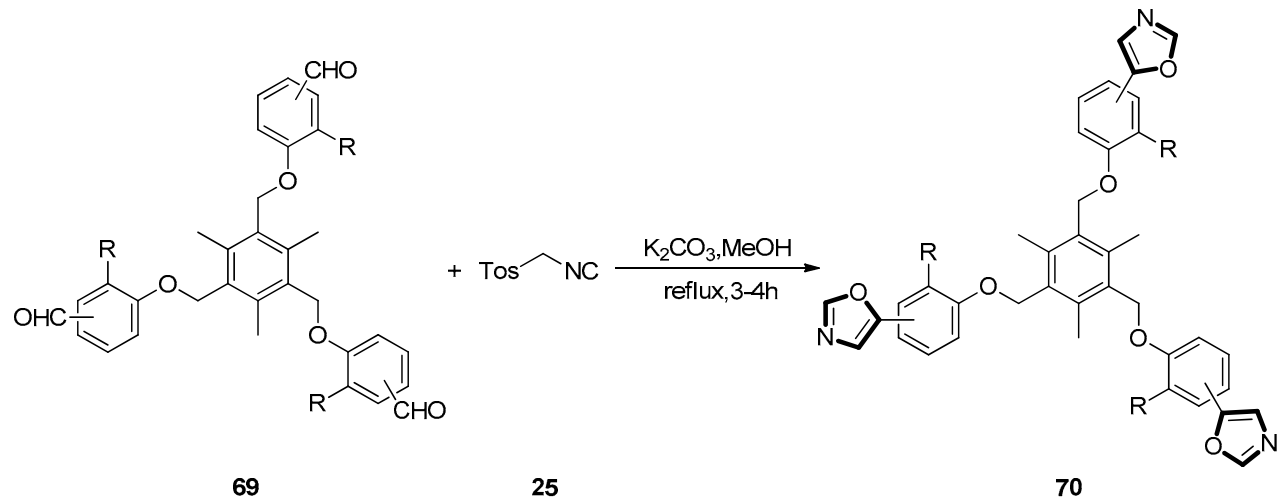

Scheme 16. Synthesis of flexible tripodal 1,3-oxazoles 70 as molecular scaffolds.

In 2016, Vinary Kumar and co-workers described a novel modified van Leusen protocol for the preparation of 5-(het)aryl oxazoles 73. They used substituted (het) aryl methyl alcohols $\mathbf{7 1}$ or benzyl bromides $\mathbf{7 2}$ as the starting materials which were converted to aldehyde through in-situ oxidation in a propylphosphonic anhydride (T3P $\left.{ }^{\circledR}\right)$-DMSO or DMSO media, respectively. Then, the homologous aldehyde reacted with TosMIC 25, giving the oxazoles under the aqueous-alcoholic $\mathrm{KOH}$ condition with the yields ranging from $61 \%$ to $90 \%$. This is the first substrate-modified van Leusen reaction which can proceed under a mild reaction condition, and it is tolerant of various functional groups with a high yield. This method is also efficient and eco-friendly, and the products are easily purified (Scheme 17) [57].

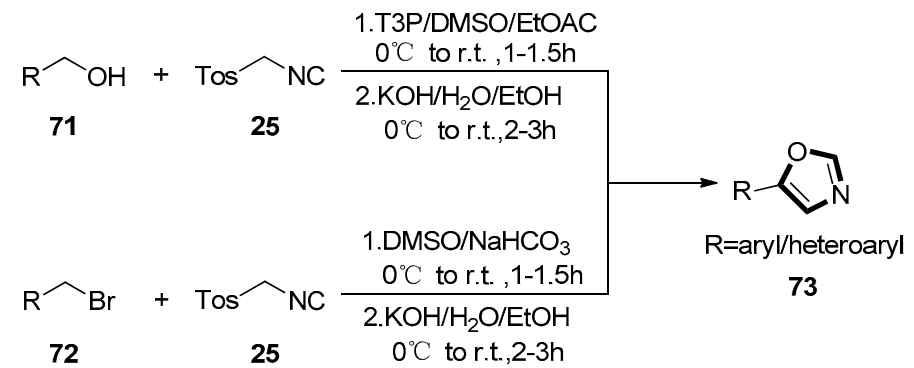

Scheme 17. A novel modified van Leusen strategy for the synthesis of 73 .

In the following year, the Ponomarenko group invented various synthetic routes for the preparation of linear phenyloxazoles and their trimethylsilane (TMS) group substituted derivatives, which could serve as the novel luminescent dye under a mild condition, by a combination of the van Leusen process and direct $\mathrm{C}-\mathrm{H}$ arylation reaction. At the first step of method A, symmetric 1,4-bis(1,3-oxazol-5-yl)benzene $\mathbf{7 5}$ was generated from terephthaloyl aldehyde $\mathbf{7 4}$ and TosMIC 25 under the typical van Leusen condition. In the method B, 1-bromo-4-(trimethylsilyl)benzene was lithiated at the first step to obtain (trimethylsilyl)benzaldehyde 77. After that, aldehyde 77 was translated into 5-substituted 4-(trimethylsilyl)phenyloxazole $\mathbf{7 8}$ with TosMIC 25 under the van Leusen condition. The target linear products $\mathbf{7 6}$ and $\mathbf{7 9}$, were generated at the following steps by direct $\mathrm{C}-\mathrm{H}$ arylation process with 4-substituted bromobenzene derivatives and 1,4-paradibromobenzene, with the yield of $80 \%$, $74 \%$, and $84 \%$, respectively (Scheme 18 ).

The synthetic scheme of the two kinds of linear phenyloxazoles was exhibited, in which method A (Scheme 18) comprises fewer reaction stages compared with the preparation of the exact 1,4-bis(5-phenyloxazol-2-yl)benzene (POPOP) structure (Scheme 18, method B). Due to the concise and efficient synthesis and excellent optical properties as well as high photo- and thermo- stability, the novel luminescent dyes might find broad application in organic photonics [58]. 


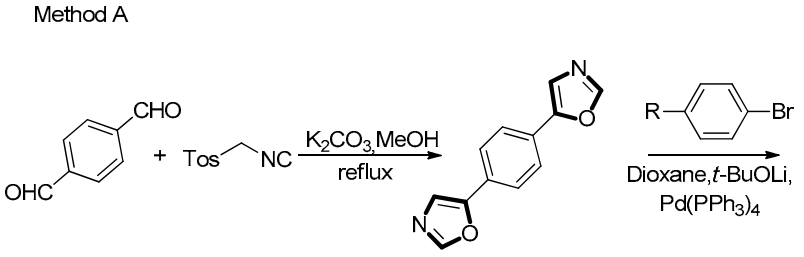

74

75

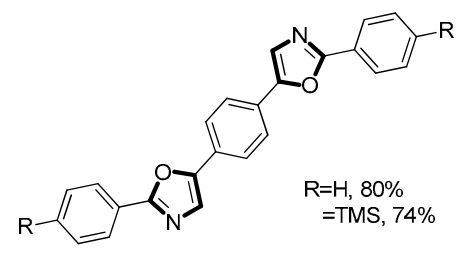

76

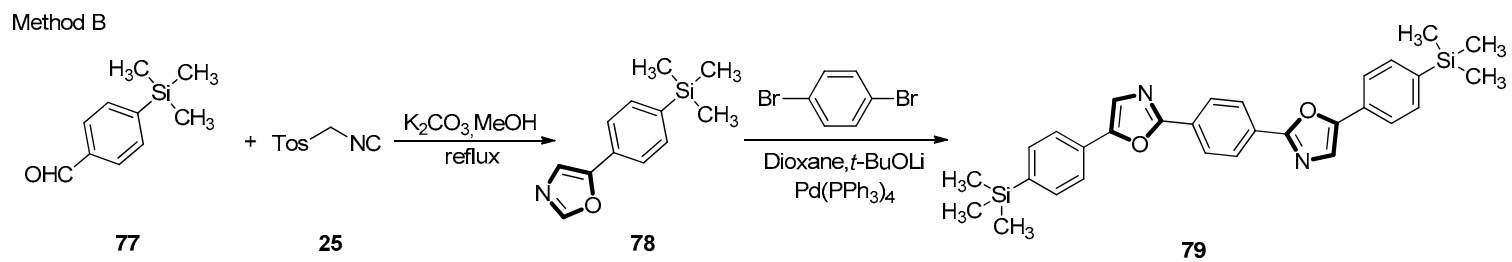

Scheme 18. Synthesis of POPOP structural isomers 76 and 79.

In 2017, Mahdavi's group described an efficient protocol for the formation of oxazoles. This approach proceeded through a unique van Leusen reaction in the presence of triethylamine and $\beta$-cyclodextrin $(\beta-C D)$ with water as solvent. The reaction was formed between diverse aldehyde substrates 80 and TosMIC 25 in a system of $\mathrm{Et}_{3} \mathrm{~N}$ and $\beta$-CD at $50{ }^{\circ} \mathrm{C}$ in water. It was clearly assured that the oxazole $\mathbf{8 1}$ was formed in an excellent yield through the analysis of the reaction mixtures. This novel approach improves the van Leusen reaction greatly since the catalytic amounts of base can be used to promote the reaction at low temperatures and water can be acted as a green media for this reaction (Scheme 19) [59].

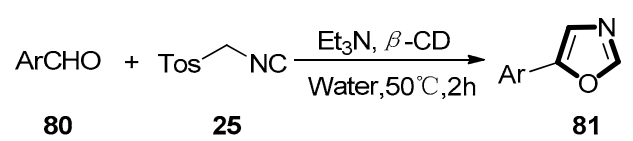

Scheme 19. Synthesis of 81 by modified van Leusen reaction using green media.

In 2017, Kotha and co-workers published a new application of a van Leusen synthesis. In this work, the van Leusen synthesis was used as a key step to construct a series of five-membered oxazole heterocycles, giving the star shaped molecules containing diverse heterocycles integrated with several variations 83 . The tri-aldehyde substrates 82 were synthesized from heterocycle derivatives through the Vilsmeier-Haack reaction under $\mathrm{K}_{2} \mathrm{CO}_{3}$ and methanol condition in a medium yield. This step had a broad substrate scope since the furan or thiophene derivatives could be synthesized equally. Then, the tri-aldehyde substrates 82 were treated with TosMIC 25, transforming into the targeted oxazole products 83 through a van Leusen route (Scheme 20). In this work, the authors also investigated the fluorescent behavior of these molecules containing $\pi$-conjugated systems. The results indicated that the $C_{3}$-Symmetric molecules containing furan moieties possessed a stronger fluorescence than thiophene-substituted star-shaped compounds [60]. 


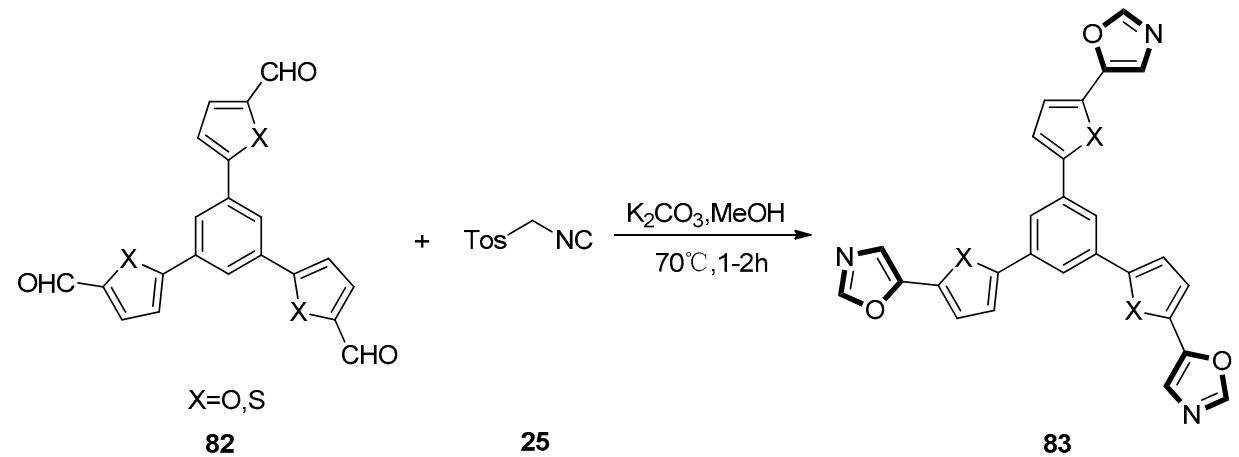

Scheme 20. Synthesis of $C_{3}$-symmetric star-shaped molecules 83 .

In 2017, Civcir et al. found a new application of the van Leusen reaction. In this work, a series of designed new molecules containing thiophene-based, furan-based oxazole, isoxazole, and isothiazole moieties were synthesized through the van Leusen reaction. By following this reaction, oxazole derivatives 85 with corresponding heterocyclic cores, were provided through the reaction of suitable 2 -formyl substituted furan or thiophene derivatives $\mathbf{8 4}$ with TosMIC 25 (Scheme 21, top). Additionally, the three ring systems of furan or thiophene 87 which had the oxazole rings substituted 87 at their 2and 5-positions, were also successfully obtained from the di-formyl substrates $\mathbf{8 6}$ (Scheme 21, bottom). This reaction was suitable for different aldehydes with furan or thiophene since both these oxazole synthetic methods occurred with good to excellent yield [61].

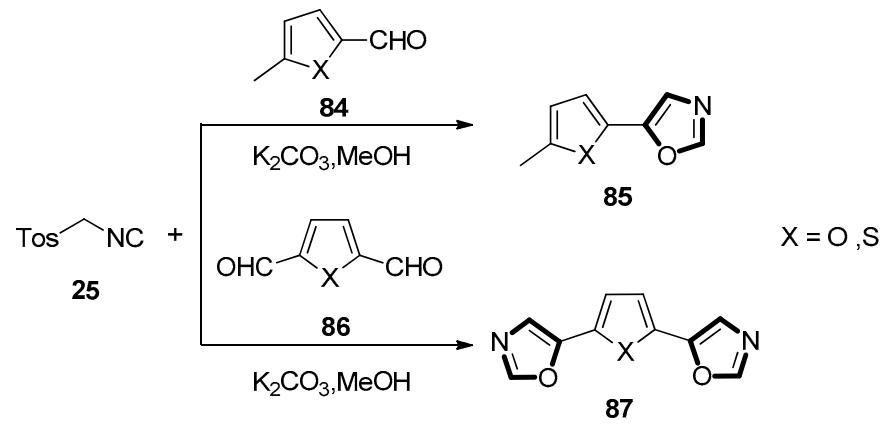

Scheme 21. Synthesis of heterocyclic systems derivatives 85 and 87 based on TosMIC.

At the same year, the Georgiades group found that oligomeric chemical compounds composed by successive $\mathrm{N}, \mathrm{O}$-heteroaromatic rings, could be introduced for products with useful and mild properties as alternative substances for biomolecular recognition. Thereupon, they developed a synthetic method based on van Leusen reaction, along with oxazoles which were formed by $\mathrm{C}-\mathrm{H}$ activation and following by their C-C cross-coupling to 2-bromopyridines in order to collect a class of variable-length, 'head-to-tail'-connected, pyridyl-oxazole ligands. For constructing the skeleton of oligomers, one of the main chemical methods was to establish which was from the conversion of aldehyde moieties 88, 90, and $\mathbf{9 2}$ to oxazoles 89, 91, and 93 with TosMIC 25 in methanol, under stepwise van Leusen synthetic oxazole. The studies inspected the effect to link with asymmetry rather than symmetry of the ligands' ingredient units, as well as the impact of ligand length, and results of these parameters, including target affinity, target stabilization, and target conformational modification. Through designing, these molecules representing new access into a series of rotationally flexible oligoaryl compounds, on account of limited rigidity and adaptability to the target surface and multivalent bonding ability, might be wonderfully suited to target sites of G-quadruplexes from those exploited by the more traditional intercalator-type ligands. Notably, they would focus on the basis of the potential function of these structures for anticancer purposes (Scheme 22) [62]. 


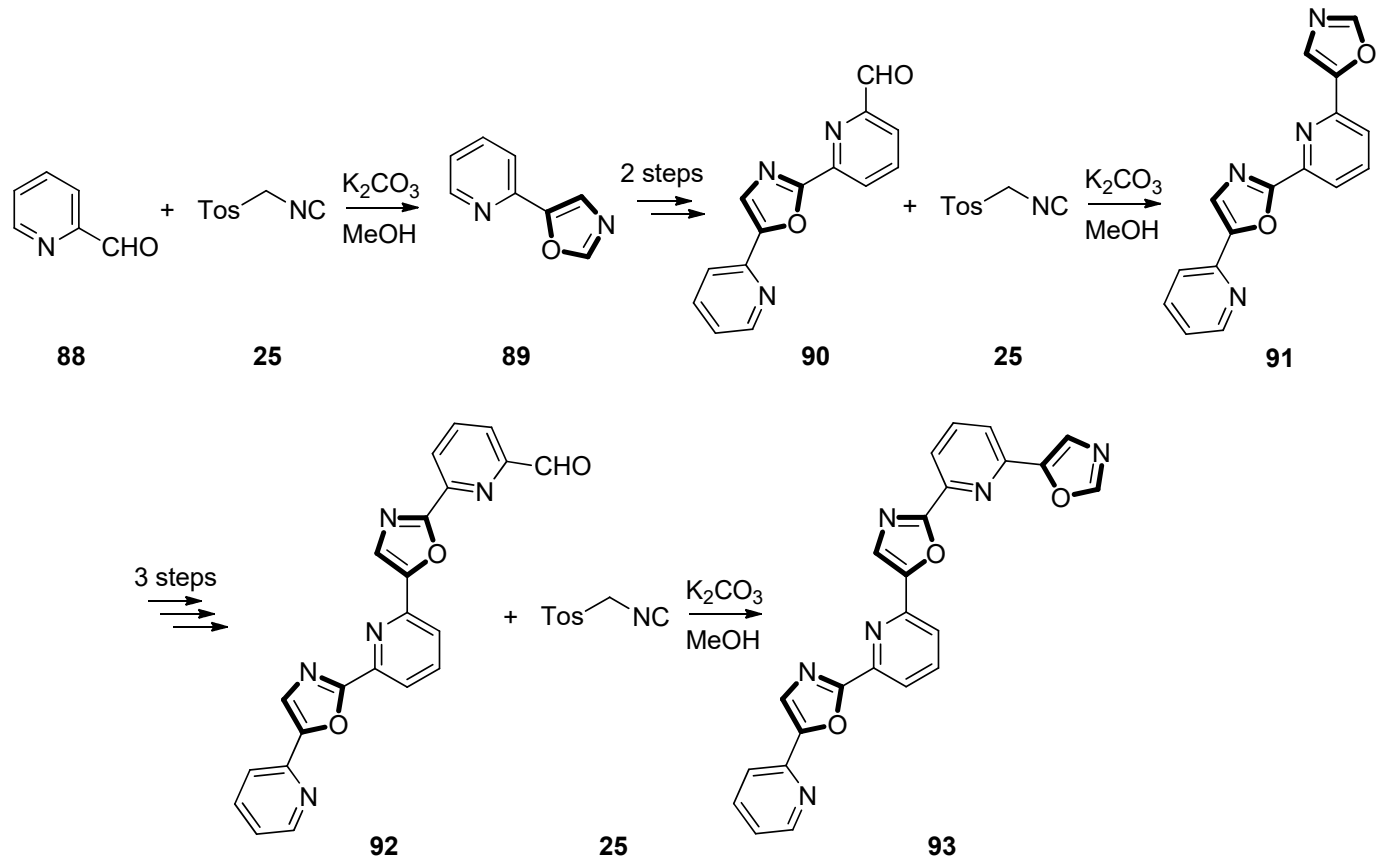

Scheme 22. Synthesis of 'head-to-tail'-connected asymmetric pyridyl-oxazoles 93 for anticancer purposes.

In 2018, Laali reported that facile synthesis of multiple $C_{5}$-substituted oxazoles derivatives $\mathbf{9 5 , 9 6}$, and 97. These products were obtained from the oxazole intermediates through the van Leusen reaction, followed by the sequential van Leusen-Suzuki, van Leusen-Heck, and van Leusen-Sonogashira coupling reactions, respectively. This method was characterized through employing imidazolium ionic liquids (imidazolium-ILs) as solvent and piperidine-appended imidazolium [PAIM] $\left[\mathrm{NTf}_{2}\right]$ as task-specific base. This reaction could proceed successfully with readily available aldehydes 94 and TosMIC 25 in a one-pot manner with a high yield. This reaction had great potential for the IL solvents which could be recycled and reused (Scheme 23) [63].

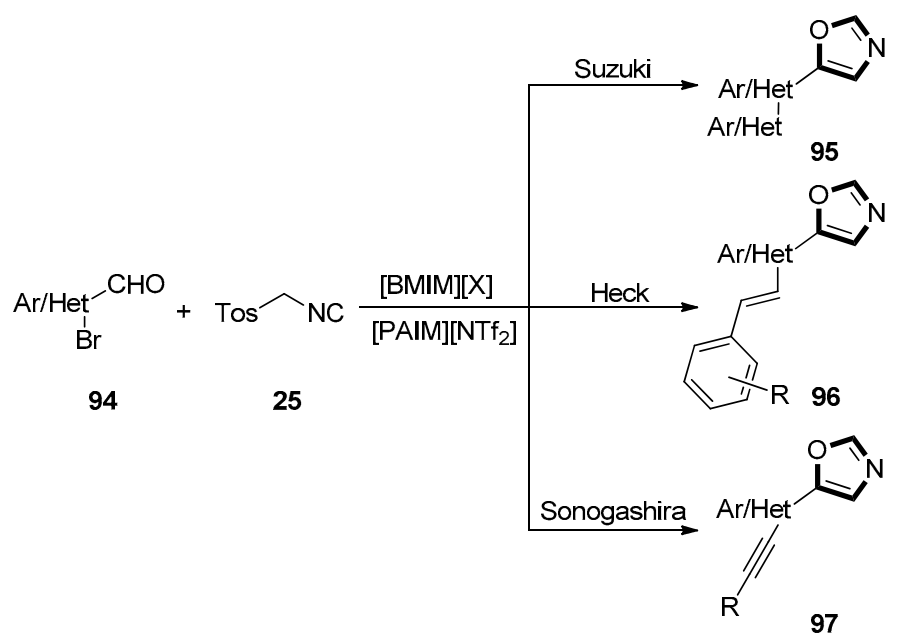

Scheme 23. Synthesis of $C_{5}$-substituted oxazoles 95,96 , and 97.

In 2019, Lechel et al. found a novel oxazole-functionalization of pyrimidine derivatives. In their study, they found that a van Leusen synthesis of 98 with TosMIC 25 could occur and give oxazole 99 in the $\mathrm{K}_{2} \mathrm{CO}_{3}$ and a methanol system in high yield. The synthesis of the novel pyrimidine derivative 99 containing three different heterocyclic substituents was unprecedented and remarkable, which 
indicated the flexibility and an application of this reaction in constructing the multi-substituted complex molecules (Scheme 24) [64].

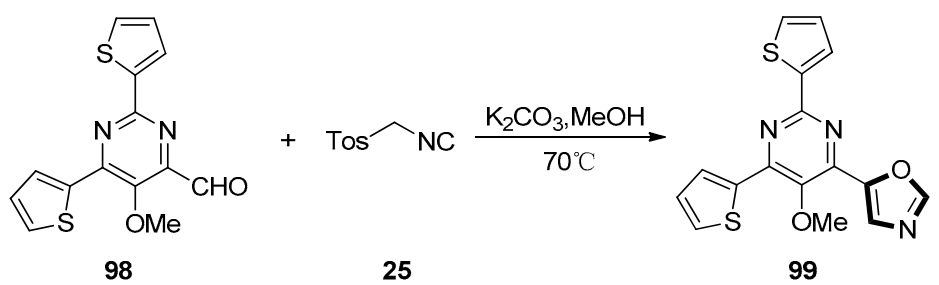

Scheme 24. Synthesis of pyrimidine derivative 99.

In the same year, Zarganes-Tzitzikas et al. developed the van Leusen reaction from formylphenylboronic ester 100. They found that the widespread applicability of oxazoles in the preparation of drugs also justified the evaluation of the compatibility of these aromatic heterocycles with the $\mathrm{Cu}$-mediated oxidative ${ }^{18} \mathrm{~F}$-fluorination method. The oxazole substituted arylboronic ester derivatives 101 were formed through the van Leusen multicomponent reaction between a 4- or 3-formylphenylboronic ester $\mathbf{1 0 0}$ and TosMIC $\mathbf{2 5}$ under microwave assisted (MW-assisted) condition. The intermediates 101 were ${ }^{18} \mathrm{~F}$-fluorinated through a Cu-mediated oxidative reaction. Both $p$ - and m-position fluorinated molecules 102 were successfully radiolabeled. The 4-fluorinated product 102a reached a higher maximum radiochemical conversion (RCC) of $67 \%$ than the 3 -fluorinated product $\mathbf{1 0 2} \mathbf{b}$ which had the maximum RCC of $38 \%$ (Scheme 25) [65].
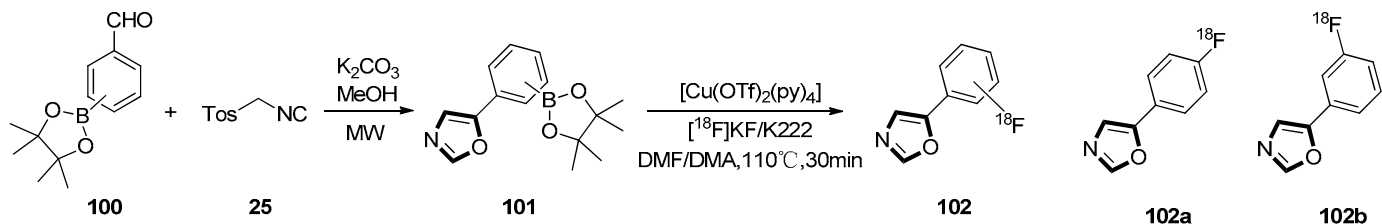

Scheme 25. Synthesis of $p$ - and m-position products 102 .

In 2019, Yasaei and co-workers described a synthesis of 5-(2-chloroquiolin-3-yl)oxazole 104. The synthesis proceeded through a van Leusen route procedure between 2-chloroquinoline-3-carbaldehydes 103 and TosMIC 25. The oxazole intermediate was efficiently subjected to the Pd-catalyzed amidation process with isocyanides to form 3-(oxazol-5-yl)quinoline-2-carboxamides. As shown in Scheme 26, subjecting 2-chloroquinoline-3-carbaldehyde 103 and TosMIC 25 to the van Leusen reaction condition generated 5-(2-tosylquinolin-3-yl)oxazole 104 in a 83\% yield after $8 \mathrm{~h}$ (Scheme 26) [66].

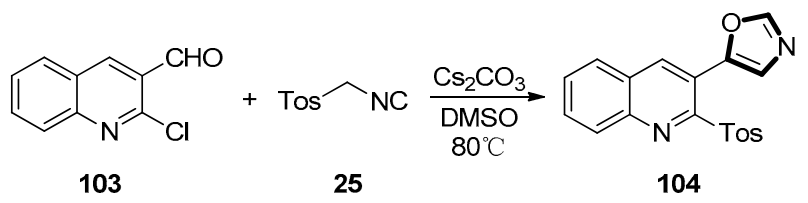

Scheme 26. Synthesis of 5-(2-tosylquinolin-3-yl)oxazole 104.

In 2020, Rashamuse et al. reported a MW-assisted van Leusen synthesis. They synthesized a series of unusual 5-aryl-4-tosyl-4,5-dihydro-1,3-oxazoles and 5-aryl-1,3-oxazole compounds 106 through a MW-assisted cycloaddition with TosMIC 25 and imines or aldehydes as starting materials. This reaction had both a high yield, efficiency, and a broad substrate scope. They extended the MW-assisted version of the van Leusen reaction of commercially available TosMIC and aldehyde to form of a small variety of 5-aryl-1,3-oxazoles 106 with anhydrous methanol as solvent (Scheme 27) [67]. 


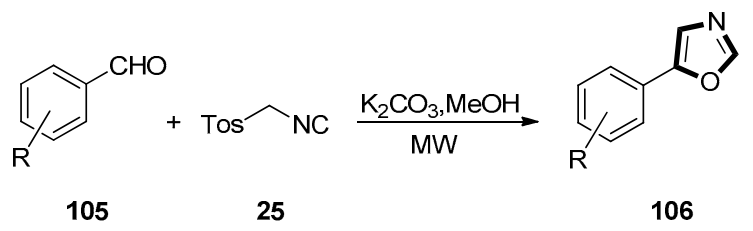

Scheme 27. Synthesis of inhibitor of microbial pathogen 106.

\section{Conclusions}

In summary, under the in-depth research and application in oxazole-based medicinal chemistry and the progress in other related disciplines such as cell biology, molecular biology, pharmacology, and organic chemistry, the synthesis of oxazole-based drugs will be still an active field in medicinal research and development industries for a long time. In the future, increasing researcher interests would be focused on the design, synthesis, bioactive evaluation, and action mechanism of unusual types of oxazole-based heterocyclic compounds with completely novel chemical scaffold, which are helpful for overcoming drug resistances, increasing bioactivities, and will make remarkable contributions to the prevention and protection of human health. Hence, we could focus on changing the starting materials including different aldehydes and TosMICs to modify oxazole-containing derivatives, or utilizing a new synthesis technology like the MW-assisted condition to improve the synthesis efficiency, or uniting other typical name reaction to synthesize the special and complex oxazole-based compounds in the future. Above all, these have clearly and strongly suggested the infinite potentiality of van Leusen oxazole synthesis in medicinal chemistry. Additionally, we hope that this review will build a full foundation and reference source, which will open up new thought for researchers to focus on oxazole-based medicinal molecule design and synthesis chemistry.

Author Contributions: All authors wrote the paper. All authors read and approved the final manuscript.

Funding: Financial support of this research provided by the Science and Technology Planning Project of Jilin Province (20160414015GH) is greatly acknowledged.

Conflicts of Interest: The authors declare no conflict of interest.

\section{References}

1. Zhang, H.Z.; Zhao, Z.L.; Zhou, C.H. Recent advance in oxazole-based medicinal chemistry. Eur. J. Med. Chem. 2018, 144, 444-492. [CrossRef] [PubMed]

2. Kaur, R.; Palta, K.; Kumar, M.; Bhargava, M.; Dahiya, L. Therapeutic potential of oxazole scaffold: A patent review (2006-2017). Expert Opin. Ther. Pat. 2018, 28, 783-812. [CrossRef] [PubMed]

3. Kakkar, S.; Narasimhan, B. A comprehensive review on biological activities of oxazole derivatives. BMC Chem. 2019, 13. [CrossRef] [PubMed]

4. Chiacchio, M.A.; Lanza, G.; Chiacchio, U.; Giofre, S.V.; Romeo, R.; Iannazzo, D.; Legnani, L. Oxazole-based compounds as anticancer agents. Curr. Med. Chem. 2019, 26, 7337-7371. [CrossRef]

5. Aljaar, N.; Gujjarappa, R.; Al-Refai, M.; Shtaiwi, M.; Malakar, C.C. Overview on recent approaches towards synthesis of 2-keto-annulated oxazole derivatives. J. Heterocycl. Chem. 2019, 56, 2730-2743. [CrossRef]

6. Škedelj, V.; Perdih, A.; Brvar, M.; Kroflič, A.; Dubbée, V.; Savage, V.; O’Neill, A.J.; Solmajer, T.; Bešter-Rogač, M.; Blanot, D.; et al. Discovery of the first inhibitors of bacterial enzyme d-aspartate ligase from Enterococcus faecium (Aslfm). Eur. J. Med. Chem. 2013, 67, 208-220. [CrossRef]

7. Li, N.N.; Xu, Y.T.; Xia, Q.; Bai, C.G.; Wang, T.Y.; Wang, L.; He, D.D.; Xie, N.N.; Li, L.X.; Wang, J.; et al. Simplified captopril analogues as NDM-1 inhibitors. Bioorgan. Med. Chem. Lett. 2014, 24, 386-389. [CrossRef]

8. Patil, P.C.; Tan, J.; Demuth, D.R.; Luzzio, F.A. 1,2,3-Triazole-based inhibitors of Porphyromonas gingivalis adherence to oral streptococci and biofilm formation. Bioorgan. Med. Chem. 2016, 24, 5410-5417. [CrossRef]

9. Tomi, I.H.R.; Tomma, J.H.; Al-Daraji, A.H.R.; Al-Dujaili, A.H. Synthesis, characterization and comparative study the microbial activity of some heterocyclic compounds containing oxazole and benzothiazole moieties. J. Saudi Chem. Soc. 2015, 19, 392-398. [CrossRef] 
10. Pedras, M.S.; Abdoli, A. Metabolism of the phytoalexins camalexins, their bioisosteres and analogues in the plant pathogenic fungus Alternaria brassicicola. Bioorgan. Med. Chem. 2013, 21, 4541-4549. [CrossRef]

11. Zhang, M.Z.; Jia, C.Y.; Gu, Y.C.; Mulholland, N.; Turner, S.; Beattie, D.; Zhang, W.H.; Yang, G.F.; Clough, J. Synthesis and antifungal activity of novel indole-replaced streptochlorin analogues. Eur. J. Med. Chem. 2017, 126, 669-674. [CrossRef] [PubMed]

12. Nagashima, S.; Matsushima, Y.; Hamaguchi, H.; Nagata, H.; Kontani, T.; Moritomo, A.; Koshika, T.; Takeuchi, M. Novel quinuclidinyl heteroarylcarbamate derivatives as muscarinic receptor antagonists. Bioorgan. Med. Chem. 2014, 22, 3478-3487. [CrossRef] [PubMed]

13. Perrone, M.G.; Vitale, P.; Panella, A.; Fortuna, C.G.; Scilimati, A. General role of the amino and methylsulfamoyl groups in selective cyclooxygenase(COX)-1 inhibition by 1,4-diaryl-1,2,3-triazoles and validation of a predictive pharmacometric PLS model. Eur. J. Med. Chem. 2015, 94, 252-264. [CrossRef] [PubMed]

14. Otrubova, K.; Cravatt, B.F.; Boger, D.L. Design, Synthesis, and Characterization of $\alpha$-Ketoheterocycles That additionally target the cytosolic port Cys269 of fatty acid amide hydrolase. J. Med. Chem. 2014, 57, 1079-1089. [CrossRef]

15. Draffan, A.G.; Frey, B.; Fraser, B.H.; Pool, B.; Gannon, C.; Tyndall, E.M.; Cianci, J.; Harding, M.; Lilly, M.; Hufton, R.; et al. Derivatives of imidazotriazine and pyrrolotriazine C-nucleosides as potential new anti-HCV agents. Bioorgan. Med. Chem. Lett. 2014, 24, 4984-4988. [CrossRef]

16. Zhong, Z.J.; Zhang, D.J.; Peng, Z.G.; Li, Y.H.; Shan, G.Z.; Zuo, L.M.; Wu, L.T.; Li, S.Y.; Gao, R.M.; Li, Z.R. Synthesis and antiviral activity of a novel class of (5-oxazolyl)phenyl amines. Eur. J. Med. Chem. 2013, 69, 32-43. [CrossRef]

17. Kim, S.H.; Markovitz, B.; Trovato, R.; Murphy, B.R.; Austin, H.; Willardsen, A.J.; Baichwal, V.; Morham, S.; Bajji, A. Discovery of a new HIV-1 inhibitor scaffold and synthesis of potential prodrugs of indazoles. Bioorgan. Med. Chem. Lett. 2013, 23, 2888-2892. [CrossRef]

18. Meissner, A.; Boshoff, H.I.; Vasan, M.; Duckworth, B.P.; Barry, C.E., III; Aldrich, C.C. Structure-activity relationships of 2-aminothiazoles effective against Mycobacterium tuberculosis. Bioorgan. Med. Chem. Lett. 2013, 21, 6385-6397. [CrossRef]

19. Abhale, Y.K.; Sasane, A.V.; Chavan, A.P.; Shekh, S.H.; Deshmukh, K.K.; Bhansali, S.; Nawale, L.; Sarkar, D.; Mhaske, P.C. Synthesis and antimycobacterial screening of new thiazolyl-oxazole derivatives. Eur. J. Med. Chem. 2017, 132, 333-340. [CrossRef]

20. Li, D.S.; Gao, N.N.; Zhu, N.Y.; Lin, Y.; Li, Y.; Chen, M.H.; You, X.F.; Lu, Y.; Wan, K.L.; Jiang, J.D.; et al. Discovery of the disubstituted oxazole analogues as a novel class anti-tuberculotic agents against MDR- and XDR-MTB. Bioorgan. Med. Chem. Lett. 2015, 25, 5178-5181. [CrossRef]

21. Lu, X.W.; Wu, Y.K. On the structure of aspongopusin recently isolated from Aspongopus chinensis. Fitoterapia 2013, 84, 318-320. [CrossRef] [PubMed]

22. Wu, C.; Liang, Z.W.; Xu, Y.Y.; He, W.M.; Xiang, J.N. Gold-catalyzed oxazoles synthesis and their relevant antiproliferative activities. Chin. Chem. Lett. 2013, 24, 1064-1066. [CrossRef]

23. Maini, R.; Dedkova, L.M.; Paul, R.; Madathil, M.M.; Chowdhury, S.R.; Chen, S.; Hecht, S.M. Ribosome-mediated incorporation of dipeptides and dipeptide analogues into proteins in vitro. J. Am. Chem. Soc. 2015, 137, 11206-11209. [CrossRef] [PubMed]

24. Taha, M.; Ismail, N.H.; Imran, S.; Anouar, E.H.; Selvaraj, M.; Jamil, W.; Ali, M.; Kashif, S.M.; Rahim, F.; Khan, K.M.; et al. Synthesis and molecular modelling studies of phenyl linked oxadiazole-phenylhydrazone hybrids as potent antileishmanial agents. Eur. J. Med. Chem. 2017, 126, 1021-1033. [CrossRef] [PubMed]

25. Yamamuro, D.; Uchida, R.; Ohtawa, M.; Arima, S.; Futamura, Y.; Katane, M.; Homma, H.; Nagamitsu, T.; Osada, H.; Tomoda, H. Synthesis and biological activity of 5-(4-methoxyphenyl)-oxazole derivatives. Bioorgan. Med. Chem. Lett. 2015, 25, 313-316. [CrossRef]

26. Da Rosa, R.; de Moraes, M.H.; Zimmermann, L.A.; Schenkel, E.P.; Steindel, M.; Bernardes, L.S.C. Design and synthesis of a new series of 3,5-disubstituted isoxazoles active against Trypanosoma cruzi and Leishmania amazonensis. Eur. J. Med. Chem. 2017, 128, 25-35. [CrossRef]

27. Yoon, D.S.; Wu, S.C.; Seethala, R.; Golla, R.; Nayeem, A.; Everlof, J.G.; Gordon, D.A.; Hamann, L.G.; Robl, J.A. Discovery of pyridyl sulfonamide 11-beta-hydroxysteroid dehydrogenase type 1 (11 $\beta$-HSD1) inhibitors for the treatment of metabolic disorders. Bioorgan. Med. Chem. Lett. 2014, 24, 5045-5049. [CrossRef] 
28. Kalwat, M.A.; Huang, Z.; Wichaidit, C.; McGlynn, K.; Earnest, S.; Savoia, C.; Dioum, E.M.; Schneider, J.W.; Hutchison, M.R.; Cobb, M.H. Isoxazole alters metabolites and gene expression, decreasing proliferation and promoting a neuroendocrine phenotype in $\beta$-Cells. ACS Chem. Biol. 2016, 11, 1128-1136. [CrossRef]

29. Zahanich, I.; Kondratov, I.; Naumchyk, V.; Kheylik, Y.; Platonov, M.; Zozulya, S.; Krasavin, M. Phenoxymethyl 1,3-oxazoles and 1,2,4-oxadiazoles as potent and selective agonists of free fatty acid receptor 1 (GPR40). Bioorgan. Med. Chem. Lett. 2015, 25, 3105-3111. [CrossRef]

30. Van Leusen, A.M.; Hoogenboom, B.E.; Siderius, H. A novel and efficient synthesis of oxazoles from tosylmethylisocyanide and carbonyl compounds. Tetrahedron Lett. 1972, 13, 2369-2372. [CrossRef]

31. Cornforth, J.W.; Huang, H.T. Synthesis of a 4-cyano-oxazole. J. Chem. Soc. 1948, 1969-1971. [CrossRef]

32. Fischer, E. Neue bildungsweise der oxazole. Eur. J. Inorg. Chem. 1896, 29, 205-214. [CrossRef]

33. Doyle, M.P.; Buhro, W.E.; Davidson, J.G.; Elliott, R.C.; Hoekstra, J.W.; Oppenhuizen, M. Lewis acid promoted reactions of diazocarbonyl compounds. 3. Synthesis of oxazoles from nitriles through intermediate. beta-imidatoalkenediazonium salts. J. Org. Chem. 1980, 45, 3657-3664. [CrossRef]

34. Dalla Vechia, L.; de Souza, R.O.M.A.; Miranda, L.S.D.E. The Dakin-West reaction: Past, present and future. Tetrahedron 2018, 74, 4359-4371. [CrossRef]

35. Wasserman, H.H.; Vinick, F.J. Mechanism of the Robinson-Gabriel synthesis of oxazoles. J. Org. Chem. 1973, 38, 2407-2408. [CrossRef]

36. Tandon, V.K.; Rai, S. p-Toluenesulfonylmethyl isocyanide: A versatile synthon in organic chemistry. Sulfur Rep. 2003, 24, 307-385.

37. Akritopoulou-Zanze, I. Isocyanide-based multicomponent reactions in drug discovery. Curr. Opin. Chem. Biol. 2008, 12, 324-331. [CrossRef]

38. Lujan-Montelongo, J.A.; Estevez, A.O.; Fleming, F.F. Alkyl sulfinates: Formal nucleophiles for synthesizing TosMIC analogs. Eur. J. Org. Chem. 2015, 2015, 1602-1605. [CrossRef]

39. Mathiyazhagan, A.D.; Anilkumar, G. Recent advances and applications of $p$-toluenesulfonylmethyl isocyanide (TosMIC). Org. Biomol. Chem. 2019, 17, 6735-6747. [CrossRef]

40. Van Leusen, D.; van Leusen, A.M. Synthetic uses of tosylmethyl isocyanide (TosMIC). Org. React. 2001, 57, 417-666.

41. Ma, Z.N.; Ma, Z.C.; Zhang, D.W. Synthesis of multi-substituted pyrrole derivatives through [3+2] cycloaddition with tosylmethylisocyanides (TosMICs) and electron-deficient compounds. Molecules 2018, 23, 2666. [CrossRef] [PubMed]

42. Zheng, X.N.; Ma, Z.N.; Zhang, D.W. Synthesis of imidazole-based medicinal molecules utilizing the van leusen imidazole synthesis. Pharmaceuticals 2020, 13, 37. [CrossRef] [PubMed]

43. Kulkarni, B.A.; Ganesan, A. A solid-phase equivalent of van Leusen's TosMIC, and its application in oxazole synthesis. Tetrahedron Lett. 1999, 40,5633-5636. [CrossRef]

44. Kulkarni, B.A.; Ganesan, A. Solution-phase parallel oxazole synthesis with TosMIC. Tetrahedron Lett. 1999, 40,5637-5638. [CrossRef]

45. Sisko, J.; Kassick, A.J.; Mellinger, R.; Filan, J.J.; Allen, A.; Olsen, M.A. An investigation of imidazole and oxazole syntheses using aryl-substituted TosMIC reagents. J. Org. Chem. 2000, 65, 1516-1524. [CrossRef] [PubMed]

46. Chakrabarty, M.; Basak, R.; Harigaya, Y.; Takayanagi, H. Reaction of 3/2-formylindoles with TosMIC: Formation of indolyloxazoles and stable indolyl primary enamines. Tetrahedron 2005, 61, 1793-1801. [CrossRef]

47. Kotha, S.; Shah, V. Synthesis of bis- and trisoxazole derivatives via Suzuki-Miyaura cross-coupling reaction and van Leusen oxazole synthesis. Synthesis 2007, 23, 3653-3658. [CrossRef]

48. Yu, X.Q.; Wu, B.; Wen, J.; Zhang, J.; Li, J.; Xiang, Y.Z. One-pot van Leusen synthesis of 4,5-disubstituted oxazoles in ionic liquids. Synlett 2009, 3, 500-504. [CrossRef]

49. Šagud, I.; Faraguna, F.; Marinić, Ž.; Šindler-Kulyk, M. Photochemical approach to naphthoxazoles and fused heterobenzoxazoles from 5-(phenyl/heteroarylethenyl)oxazoles. J. Org. Chem. 2011, 76, 2904-2908. [CrossRef]

50. Šagud, I.; Božić, S.; Marinić, Ž.; Šindler-Kulyk, M. Photochemical approach to functionalized benzobicyclo [3.2.1]octene structures via fused oxazoline derivatives from 4- and 5-(o-vinylstyryl)oxazoles. Beilstein J. Org. Chem. 2014, 10, 2222-2229. [CrossRef] 
51. Šagud, I.; Šindler-Kulyk, M.; Škorić, I.; Kelava, V.; Marinić, Ž. Synthesis of naphthoxazoles by photocyclization of 4-/5-(phenylethenyl)oxazoles. Eur. J. Org. Chem. 2018, 2018, 3326-3335. [CrossRef]

52. Hamon, F.; Largy, E.; Guedin-Beaurepaire, A.; Rouchon-Dagois, M.; Sidibe, A.; Monchaud, D.; Mergny, J.L.; Riou, J.F.; Nguyen, C.H.; Teulade-Fichou, M.P. An acyclic oligoheteroaryle that discriminates strongly between diverse G-quadruplex topologies. Angew. Chem. Int. Ed. 2011, 50, 8745-8749. [CrossRef] [PubMed]

53. Zhang, M.Z.; Chen, Q.; Mulholland, N.; Beattie, D.; Irwin, D.; Gu, Y.C.; Yang, G.F.; Clough, J. Synthesis and fungicidal activity of novel pimprinine analogues. Eur. J. Med. Chem. 2012, 53, 283-291. [CrossRef] [PubMed]

54. Lee, J.S.; Shin, J.; Lee, H.S.; Shin, H.J.; Lee, Y.J. A coise and rapid approach to the marine natural product streptochlorin and its analogues. Bull. Korean Chem. Soc. 2013, 34, 357-358. [CrossRef]

55. Georgiades, S.; Rizeq, N. Synthesis of a 'propeller-like' oligoheteroaryl with alternating pyridine and oxazole motifs. Synlett 2015, 26, 489-493. [CrossRef]

56. Shah, S.; Thakore, R.; Vyas, T.; Sridhar, B. Conformationally flexible $C_{3}$-symmetric 1,3-oxazoles as molecular scaffolds. Synlett 2016, 27, 294-300. [CrossRef]

57. Sadashiva, M.; Rangappa, K.; Vinay Kumar, K.; Swaroop, T.; Rajeev, N.; Vinayaka, A.; Lingaraju, G. A one-pot tandem approach for the synthesis of 5-(het)aryloxazoles from substituted (het)aryl methyl alcohols and benzyl bromides. Synlett 2016, 27, 1363-1366.

58. Skorotetcky, M.S.; Borshchev, O.V.; Surin, N.M.; Odarchenko, Y.; Pisarev, S.A.; Peregudova, S.M.; Törnroos, K.W.; Chernyshov, D.; Ivanov, D.A.; Ponomarenko, S.A. Synthesis and photostability of 1,4-bis(5-phenyloxazol-2-yl)benzene (POPOP) structural isomers and their trimethylsilyl derivatives. Dyes Pigments 2017, 141, 128-136. [CrossRef]

59. Rahimzadeh, G.; Kianmehr, E.; Mahdavi, M. Improvement of the van Leusen reaction in the presence of $\beta$-cyclodextrin: A green and efficient synthesis of oxazoles in water. Z. Naturforsch. B 2017, 72, 923-926. [CrossRef]

60. Kotha, S.; Todeti, S.; Gopal, M.B.; Datta, A. Synthesis and photophysical properties of c 3-symmetric star-shaped molecules containing heterocycles such as furan, thiophene, and oxazole. ACS Omega 2017, 2, 6291-6297. [CrossRef]

61. Civcir, P.Ü.; Kurtay, G.; Sarıkavak, K. Experimental and theoretical investigation of new furan and thiophene derivatives containing oxazole, isoxazole, or isothiazole subunits. Struct. Chem. 2017, 28, 773-790. [CrossRef]

62. Rizeq, N.; Georgiades, S.N. Investigation of 'head-to-tail'-connected oligoaryl N,O-ligands as recognition motifs for cancer-relevant G-quadruplexes. Molecules 2017, 22, 2160. [CrossRef] [PubMed]

63. Savanur, H.M.; Kalkhambkar, R.G.; Laali, K.K. Libraries of C-5 substituted imidazoles and oxazoles by sequential van Leusen (vL)-Suzuki, vL-Heck and vL-Sonogashira in imidazolium-ILs with piperidine-appended-IL as base. Eur. J. Org. Chem. 2018, 2018, 5285-5288. [CrossRef]

64. Lechel, T.; Kumar, R.; Bera, M.K.; Zimmer, R.; Reissig, H.U. The LANCA three-component reaction to highly substituted beta-ketoenamides-Versatile intermediates for the synthesis of functionalized pyridine, pyrimidine, oxazole and quinoxaline derivatives. Beilstein J. Org. Chem. 2019, 15, 655-678. [CrossRef] [PubMed]

65. Zarganes-Tzitzikas, T.; Clemente, G.; Elsinga, P.; Dömling, A. MCR scaffolds get hotter with ${ }^{18}$ F-labeling. Molecules 2019, 24, 1327. [CrossRef]

66. Yasaei, Z.; Mohammadpour, Z.; Shiri, M.; Tanbakouchian, Z.; Fazelzadeh, S. Isocyanide reactions toward the synthesis of 3-(oxazol-5-yl)quinoline-2-carboxamides and 5-(2-tosylquinolin-3-yl)oxazole. Front. Chem. 2019, 7, 433. [CrossRef]

67. Rashamuse, T.J.; Harrison, A.T.; Mosebi, S.; van Vuuren, S.; Coyanis, E.M.; Bode, M.L. Design, synthesis and biological evaluation of imidazole and oxazole fragments as HIV-1 integrase-LEDGF/p75 disruptors and inhibitors of microbial pathogens. Bioorgan. Med. Chem. 2020, 28, 115210. [CrossRef]

(C) 2020 by the authors. Licensee MDPI, Basel, Switzerland. This article is an open access article distributed under the terms and conditions of the Creative Commons Attribution (CC BY) license (http://creativecommons.org/licenses/by/4.0/). 